\title{
Collagen-Coated Superparamagnetic Iron Oxide Nanoparticles as a Sustainable Catalyst for Spirooxindole Synthesis
}

Shima Ghanbari

Iran University of Science and Technology

Maryam Esmkhani

Iran University of Science and Technology

Shahrzad Javanshir ( $\nabla$ shjavan@iust.ac.ir)

Iran University of Science and Technology

\section{Research Article}

Keywords: catalysis, nanoparticles, catalytic properties

Posted Date: May 13th, 2021

DOI: https://doi.org/10.21203/rs.3.rs-509159/v1

License: (c) (i) This work is licensed under a Creative Commons Attribution 4.0 International License.

Read Full License 


\section{Abstract}

In this work, a novel magnetic organic-inorganic hybrid catalyst was fabricated by encapsulating magnetite@silica (Fe304@SiO2) nanoparticles with Isinglass protein collagen (IGPC) using epichlorohydrin $(\mathrm{ECH})$ as crosslinking agent. Characterization studies of the prepared particles were accomplished by various analytical techniques specifically, Fourier transform infrared (FTIR) analysis, scanning electron microscopy (SEM), transmission electron microscopy (TEM), vibrating sample magnetometry (VSM), energy dispersive X-ray (EDX), X-ray diffraction (XRD), and Brunauer-Emmett-Teller (BET) analysis. The XRD results showed a crystalline and amorphous phase which contribute to magnetite and isinglass respectively. Moreover, the formation of the core/shell structure had been confirmed by TEM images. The synthesized Fe304@SiO2/ECH/IG was applied as bifunctional heterogeneous catalyst in the synthesis of spirooxindole derivatives demonstrating excellent catalytic properties, stability and recyclability.

\section{Introduction}

Nowadays, the use of bifunctional catalysts has become a new field to promote chemical reactions in green, and environmentally friendly pathways and processes. In order to develop new approaches that are more respectful of the environment, catalyst development strategies are now oriented towards polymers of natural origin such as polysaccharides or proteins which come from renewable resources, often biocompatible and also more biodegradable than their synthetic counterparts. Bio-based heterogeneous catalysts, prepared from renewable natural polymers, have received significant attention in recent years due to their substantial advantages such as biodegradability, stability, and recyclability. The combination of nanoparticles and biodegradable polymers can result in nano-biocomposites, which have the potential for various catalytic and environmental applications ${ }^{1-5}$.

Plentiful supports have been commonly used for the immobilization of natural polymers such as silica, resins, silica composites, and magnetic materials among others. Magnetic nanoparticles based on metals such as $\mathrm{Cu}, \mathrm{Co}, \mathrm{Fe}$, and Ni provide a potent solid support system to immobilize proteins ${ }^{6-10}$, among them, magnetite nanoparticles $\left(\mathrm{Fe}_{3} \mathrm{O}_{4}\right)$ have remarkable properties such as superparamagnetism, low toxicity, high specific surface area, biocompatibility and easy separation which makes them more interesting for researchers.

One of the most commonly used techniques for the immobilization of proteins is cross-linking. For collagen materials, many crosslinkers such as glutaraldehyde, isocyanates, glyoxal, and carbodiimides, were used ${ }^{11}$.

Natural polymers such as polysaccharides (cellulose, chitosan, chitin, alginate, carrageenan, lignin, fucoidan, etc.) and proteins have been used as catalysts in chemical transformations ${ }^{12-18}$. Coating magnetic particles with natural polymers allows them to use their functional groups for promoting chemical reactions and also easy separation ${ }^{19,20}$. 
Based on our interest for turning agricultural and marine waste into value added materials, $\left[{ }^{21-23}\right]$ we have used Isinglass (IG), a natural polymer derived from swim bladder of fish with high content of collagen protein, for encapsulating $\mathrm{Fe}_{3} \mathrm{O}_{4} @ \mathrm{SiO}_{2}$ nanoparticles using epichlorohydrin $(\mathrm{ECH})$ as crosslinking agent. The prepared hybrid material named $\mathrm{Fe}_{3} \mathrm{O}_{4} @ \mathrm{SiO}_{2} / \mathrm{ECH} / \mathrm{IG}$ was applied as bifunctional heterogeneous catalyst in the synthesis of spirooxindole derivatives. Such hybrid material based on natural polymer IG with both acidic and basic groups has been shown to be a very effective catalyst in a variety of chemical transformation, including the synthesis of, triazoles ${ }^{24}, 4 H$-pyran derivatives ${ }^{25}$, and Suzuki coupling ${ }^{26}$. IG contains many amino acids whom their properties and catalytic performances have been demonstrated for many years ${ }^{27,28}$.

Defined as processes allowing at least three reagents to react in a single pot, all of which participate in the structure of the final product, multicomponent reactions make it possible to synthesize highly functionalized compounds. In addition, multicomponent reactions offer rapid access to a wide variety of potential active ingredients. In the same way that a 4-digit code offers 10,000 possibilities, the possible variations for each reagent give access to an impressive number of related compounds. Very useful in combinatorial chemistry, MCRs make it possible to constitute chemical libraries for high throughput screening in the pharmaceutical industry. Several evocative tags are commonly involved in MCRs such as the atomic economy, easy to implement, using very mild reaction conditions, and without recourse to toxic metals, these reactions represent a definite step forward to ideal synthesis ${ }^{29,30}$.

Heterocyclic compounds represent more than $90 \%$ of the active ingredients possessing a wide range of applications in pharmaceutical industry, veterinary medicine and phytochemistry ${ }^{31}$. Indoles, oxindoles, and spirooxindoles are important heterocyclic compounds, and ubiquitous motifs in naturally and unnaturally occurring biologically active pharmaceutical ingredients $292,30,314$. Some biologically active indoles, oxindoles and spirooxindoles are presented in figure 1.

So far, various methods and catalysts have been used for the synthesis of these compounds, including the reaction between isatin, malononitrile and dimedone with different catalysts such as a-amylase ${ }^{32}$, $\mathrm{CoFe}_{2} \mathrm{O}_{4} @ \mathrm{SiO}_{2} @ \mathrm{SO}_{3} \mathrm{H}^{33}, \mathrm{MgO} @ \mathrm{PMO}-\mathrm{IL}^{34}$, magnetic sulfonated chitosan ${ }^{35}$, magnetic poly ethyleneimine ${ }^{36}$, etc.

Here, we have developed a new collagen-coated superparamagnetic iron oxide nanoparticle as a sustainable bio-based catalyst for the direct synthesis of spirooxindole (Figure 2).

\section{Results And Discussion}

Synthesis pathway of $\mathrm{Fe}_{3} \mathrm{O}_{4} @ \mathrm{SiO}_{2} / \mathrm{ECH} / \mathrm{IG}$ is illustrated in figure 2. $\mathrm{Fe}_{3} \mathrm{O}_{4} \mathrm{NPs}$ were prepared by coprecipitation method by dissolving divalent and trivalent iron salts into distilled water, followed by precipitation with $\mathrm{NH}_{4} \mathrm{OH}$ Afterward, TEOS was hydrolyzed to form silica oligomers, which were coated on the surface of $\mathrm{Fe}_{3} \mathrm{O}_{4}$ nanoparticles to obtain $\mathrm{Fe}_{3} \mathrm{O}_{4} @ \mathrm{SiO}_{2}$ nanoparticles. Subsequently, $\mathrm{ECH}$ was cross- 
linked on the surface of $\mathrm{Fe}_{3} \mathrm{O}_{4} / \mathrm{SiO}_{2}$. $\mathrm{Fe}_{3} \mathrm{O}_{4} @ \mathrm{SiO}_{2} / \mathrm{ECH} / \mathrm{IG}$ was obtained by nucleophilic addition of IG to as-prepared magnetic nanoparticles. (figure 2)

\section{Characterization of the $\mathrm{Fe}_{3} \mathrm{O}_{4} @ \mathrm{SiO}_{2} / \mathrm{ECH} / \mathrm{IG}$}

After preparation of the nanocatalyst, its composition, structure, morphology and textural properties was properly characterized by different methods and techniques. The FT-IR spectra of the $\mathrm{Fe}_{3} \mathrm{O}_{4} @ \mathrm{SiO}_{2} / \mathrm{ECH} / \mathrm{IG}, \mathrm{Fe}_{3} \mathrm{O}_{4} @ \mathrm{SiO}_{2}$, and $\mathrm{Fe}_{3} \mathrm{O}_{4}$ are compared in Figure $\mathrm{S} 1$ (see supporting information). The three curves show variation in the intensity of the bands in different regions. The FTIR spectrum of $\mathrm{Fe}_{3} \mathrm{O}_{4}$ indicates the characteristic band of $\mathrm{Fe}-\mathrm{O}$ at $596 \mathrm{~cm}^{-1}$. The peak identified at $3426 \mathrm{~cm}^{-1}$ which was assigned to the $\mathrm{O}-\mathrm{H}$ stretching vibrations was shifted from 3426 to $3276 \mathrm{~cm}^{-1}$ in $\mathrm{Fe}_{3} \mathrm{O}_{4} @ \mathrm{SiO}_{2} / \mathrm{ECH} / \mathrm{IG}$ with a net diminution of intensity indicating the involvement of isinglass in the synthesis of final composite. The characteristic bands appeared at 1400,1385 and $1220 \mathrm{~cm}^{-1}$ were attributed to $\mathrm{C}-0$ (carboxyl), $\mathrm{C}-\mathrm{OH}$ (secondary) and $\mathrm{C}-\mathrm{O}$ groups. Finally, this FT-IR spectrum can be clearly shown that the $\mathrm{Fe}_{3} \mathrm{O}_{4} @ \mathrm{SiO}_{2} / \mathrm{ECH} / \mathrm{IG}$ was successfully prepared.

The morphology and the structure of the $\mathrm{Fe}_{3} \mathrm{O}_{4} @ \mathrm{SiO}_{2} / \mathrm{ECH} / \mathrm{IG}$ was characterized by SEM and TEM analysis (figure $3 a$ and $b$ ). The average particle size was estimated to be $58 \mathrm{~nm}$. Moreover, the wellordered structure of the catalyst and its almost uniform distribution are clearly observable (Fig. 3a). The core-shell structure of the magnetic particles was proofed with the black centres and the brightest areas as $\mathrm{Fe}_{3} \mathrm{O}_{4}$ cores and $\mathrm{SiO}_{2}$ shells respectively. These images also approve that the particles are nanometric in size (Fig. 3b).

Furthermore, the presence of carbon, oxygen, nitrogen, iron and Si elements were confirmed by energy dispersive X-ray (EDX) analysis which was showed in Figure $4 a$ and $b$.

The magnetic features of $\mathrm{Fe}_{3} \mathrm{O}_{4}, \mathrm{Fe}_{3} \mathrm{O}_{4} @ \mathrm{SiO}_{2}$ and $\mathrm{Fe}_{3} \mathrm{O}_{4} @ \mathrm{SiO}_{2} / \mathrm{ECH} / \mathrm{IG}$ were investigated using VSM analysis. Magnetic hysteresis loop measurements of $\mathrm{Fe}_{3} \mathrm{O} 4 @ \mathrm{SiO}_{2} / \mathrm{ECH} / \mathrm{IG}$ indicate that its saturation magnetization value (17.162 emus. $\left.\mathrm{g}^{-1}\right)$ is less than $\mathrm{Fe}_{3} \mathrm{O}_{4}\left(63.9\right.$ emus. $\left.\mathrm{g}^{-1}\right)$. This value demonstrated the incorporation of IG on the surface of $\mathrm{Fe}_{3} \mathrm{O}_{4}$ (Figure 5).

In addition, in XRD pattern (figure 6) the peaks in 35, 57, and 62 were assigned to the presence of $\mathrm{Fe}_{3} \mathrm{O}_{4}$ in structure. The broad peak at 10-20 attributed to the amorphous structure of isinglass. The patterns were compared in X'pert software and correspond with 00-001-1111, 00-002-0459 reference card numbers. (The individual reference card numbers were collected from the X'pert HighScore Plus version 1.0d software developed by the PANalytical B.V.)

According to the results of BET analysis shown in figure S2 (see supporting information), the special surface area $8.6115 \mathrm{~m}^{2} \mathrm{~g}^{-1}$ and the volume of $\mathrm{P} / \mathrm{P}^{\circ}$ is $0.298949197 \mathrm{~cm}^{3} \mathrm{~g}^{-1}$. Also, the volume of the single-point adsorption cavity and the single-point cavity desorption volume is $0.051635 \mathrm{~cm}^{3} / \mathrm{g}$ and $0.045370 \mathrm{~cm}^{3} / \mathrm{g}$ respectively. 


\section{Investigation the catalytic activities of $\mathrm{Fe}_{3} \mathrm{O}_{4} @ \mathrm{SiO}_{2} / \mathrm{ECH} / \mathrm{IG}$ for the synthesis of spirooxindole derivatives}

4a-t

The catalytic behavior of $\mathrm{Fe}_{3} \mathrm{O}_{4} @ \mathrm{SiO}_{2} / \mathrm{ECH} / \mathrm{IG}$ was investigated for the synthesis of spirooxindole derivatives via a three- component reaction between $\mathrm{CH}$-acids, malononitrile, and isatin derivatives under different conditions. To find the optimal reaction conditions, various factors such as catalyst loading, solvent, time and reaction temperature were scrutinized in a model reaction including dimedone (1a), malononitrile (2a), and isatin ( $\mathbf{3 a}$ ) to estimate the proper catalytic loading and time (figure $\mathbf{7})$. Amid different solvents, the mixture of $\mathrm{EtOH} / \mathrm{H}_{2} \mathrm{O}(1: 1)$ was completed in a shorter time and gave a better yield (Table S1).

For further optimization, the effect of temperature, type of catalyst, and the amount of catalyst were also investigated and tabulated in Table S2 and S3 (See supporting information).

The results revealed the high performance of $\mathrm{Fe}_{3} \mathrm{O}_{4} @ \mathrm{SiO}_{2} / \mathrm{ECH} / \mathrm{IG}$ due to synergistic effects and improved number of active sites on surface. The highest conversion of $94 \%$ was attained at a catalyst loading of $10 \mathrm{mg}$ and reaction temperature $60^{\circ} \mathrm{C}$.

To generalize the optimum conditions, different spirooxindole derivatives from 4a-t were prepared through a one pot reaction of isatin derivatives 1, malononitrile 2 and 1,3 dicarbonyl derivatives $\mathbf{3 a - 3 e}$ in the presence of $\mathrm{Fe}_{3} \mathrm{O}_{4} @ \mathrm{SiO}_{2} / \mathrm{ECH} / \mathrm{IG}$. (figure 7). The results are summarized in table 1.

Table 1 Synthesis of spirooxindole derivatives in the presence of $\mathrm{Fe}_{3} \mathrm{O}_{4} @ \mathrm{SiO}_{2} / \mathrm{ECH} / \mathrm{IG}$ 


\begin{tabular}{|c|c|c|c|c|c|c|c|}
\hline Entry & $\mathrm{R}_{1}$ & $\mathrm{R}_{2}$ & 1,3-dicarbonyl compound & Time (min) & $\begin{array}{l}\text { Yield } \\
\text { (\%) }\end{array}$ & $\begin{array}{c}\text { m.p. } \\
{ }^{\circ} \mathrm{C} \text { (reported) }\end{array}$ & Product \\
\hline 1 & $\mathrm{H}$ & $\mathrm{H}$ & $3 a$ & 10 & 94 & $\begin{array}{c}301-303 \\
(302-306)^{40}\end{array}$ & $4 a$ \\
\hline 2 & $\mathrm{H}$ & $\mathrm{H}$ & $3 b$ & 10 & 88 & $\begin{array}{c}282-284 \\
(278-280)^{41}\end{array}$ & $4 \mathrm{~b}$ \\
\hline 3 & $\mathrm{H}$ & $\mathrm{H}$ & $3 c$ & 20 & 81 & $\begin{array}{c}267-268 \\
(268-270)^{41}\end{array}$ & 4c \\
\hline 4 & $\mathrm{H}$ & $\mathrm{H}$ & $3 d$ & 15 & 85 & $\begin{array}{c}230-232 \\
(240-241)^{372}\end{array}$ & $4 d$ \\
\hline 5 & $\mathrm{H}$ & $\mathrm{H}$ & $3 e$ & 25 & 80 & $\begin{array}{c}301-303 \\
(290-292)^{21}\end{array}$ & $4 \mathrm{e}$ \\
\hline 6 & $\mathrm{H}$ & $\mathrm{NO}_{2}$ & $3 a$ & 10 & 89 & $\begin{array}{c}>300 \\
(302-304)^{383}\end{array}$ & $4 \mathrm{f}$ \\
\hline 7 & $\mathrm{H}$ & $\mathrm{NO}_{2}$ & $3 b$ & 5 & 85 & $\begin{array}{c}>300 \\
(306-307)^{394}\end{array}$ & $4 \mathrm{~g}$ \\
\hline 8 & $\mathrm{H}$ & $\mathrm{NO}_{2}$ & $3 c$ & 5 & 93 & $\begin{array}{c}286-288 \\
(288-289)^{405}\end{array}$ & $4 \mathrm{~h}$ \\
\hline 9 & $\mathrm{H}$ & $\mathrm{NO}_{2}$ & $3 d$ & 10 & 98 & $\begin{array}{c}240-242 \\
(253-255)^{416}\end{array}$ & $4 \mathrm{i}$ \\
\hline 10 & $\mathrm{H}$ & $\mathrm{NO}_{2}$ & $3 e$ & 30 & 82 & $\begin{array}{c}297-299 \\
(294-296)^{427}\end{array}$ & $4 j$ \\
\hline 11 & $\mathrm{H}$ & $\mathrm{Cl}$ & $3 c$ & 20 & 70 & $\begin{array}{c}234-236 \\
(240-242)^{43}\end{array}$ & $4 \mathrm{k}$ \\
\hline 12 & $\mathrm{H}$ & $\mathrm{Cl}$ & $3 e$ & 30 & 79 & $\begin{array}{c}>300 \\
(300-302)^{43}\end{array}$ & 41 \\
\hline 13 & $\mathrm{Bn}$ & $\mathrm{H}$ & $3 a$ & 10 & 86 & $\begin{array}{c}284-286 \\
(281-282)^{44}\end{array}$ & $4 \mathrm{~m}$ \\
\hline 14 & $\mathrm{Bn}$ & $\mathrm{H}$ & $3 b$ & 5 & 92 & $\begin{array}{c}282-284 \\
(282-284)^{45}\end{array}$ & $4 n$ \\
\hline 15 & $\mathrm{Bn}$ & $\mathrm{H}$ & $3 e$ & 30 & 88 & $\begin{array}{c}273-275 \\
(280-282)^{46}\end{array}$ & 40 \\
\hline 16 & $\mathrm{Me}$ & $\mathrm{H}$ & $3 a$ & 10 & 80 & $\begin{array}{c}260-262 \\
(255-258)^{47}\end{array}$ & $4 p$ \\
\hline 17 & $\mathrm{Me}$ & $\mathrm{H}$ & $3 b$ & 10 & 83 & $\begin{array}{c}244-246 \\
(243-245)^{48}\end{array}$ & $4 q$ \\
\hline 18 & $\mathrm{Me}$ & $\mathrm{H}$ & $3 c$ & 35 & 94 & $\begin{array}{c}279-281 \\
(285-286)^{49}\end{array}$ & $4 r$ \\
\hline 19 & $\mathrm{Me}$ & $\mathrm{H}$ & $3 d$ & 15 & 92 & $\begin{array}{c}274-276 \\
(280-282)^{50}\end{array}$ & $4 \mathrm{~s}$ \\
\hline
\end{tabular}


*Reaction condition: Isatin 1 (1 mmol), 2 (1 mmol), 1,3-dicarbonyl 3 (1 mmol), $10 \mathrm{mg}$ catalyst, and $3 \mathrm{ml}$ solvent at $60{ }^{\circ} \mathrm{C}$

\section{Catalyst Recyclability}

The easy separation of $\mathrm{Fe}_{3} \mathrm{O}_{4} @ \mathrm{SiO}_{2} / \mathrm{ECH} / \mathrm{IG}$ heterogenious catalyst was mentioned further. In this regard, the recyclability of the nanocatalyst in the model reaction was investigated. At the end of the reaction, $\mathrm{Fe}_{3} \mathrm{O}_{4} @ \mathrm{SiO}_{2} / \mathrm{ECH} / \mathrm{IG}$ was collected by an external magnetic field and washed with ethanol and water. The dried magnetic nanocatalyst was successively used for four times in the model reaction with a yield as $89 \%$. According to the results displayed in Figure S3(see supporting information), there is no significant reduction in the catalytic efficiency of $\mathrm{Fe}_{3} \mathrm{O}_{4} @ \mathrm{SiO}_{2} / \mathrm{ECH} / \mathrm{IG}$. FTIR spectra of the recycled catalyst were recorded after multiple cycles and compared with the fresh catalyst (Figure S1). It is clear that the used catalyst has not endure any structural changes.

In order to demonstrate the efficacy of the prepared $\mathrm{Fe}_{3} \mathrm{O}_{4} @ \mathrm{SiO}_{2} / \mathrm{ECH} / \mathrm{IG}$ catalyst, the catalytic activity in the preparation of spirooxindole derivatives was compared with the previous reports. It has several advantages over the reported studies which can be seen in table 2 .

Table 2. Comparison of the present catalyst for the synthesis of spirooxindole derivatives with reported studies

\begin{tabular}{|c|c|c|c|c|c|}
\hline Entry & Catalyst & Conditions & Time(min) & Yield(\%) & References \\
\hline $\mathbf{1}$ & [Bmim]OH & Solvent free/R.T. & 600 & 98 & 52 \\
\hline $\mathbf{2}$ & $\begin{array}{c}\text { Tris-hydroxymethyl } \\
\text { aminomethane }\end{array}$ & Ethanol/R.T. & 240 & 94 & 53 \\
\hline $\mathbf{3}$ & Trisodium citrate dihydrate & EtOH:Water/R.T. & 120 & 96 & 54 \\
\hline $\mathbf{4}$ & $\mathrm{Fe}_{3} \mathrm{O}_{4} @ \mathrm{SiO}_{2} / \mathrm{ECH} / \mathrm{IG}$ & EtOH:Water/60 & \\
\hline
\end{tabular}

\section{Experimental Section}

\section{Reagents and Apparatus}

All reagents and materials were purchased from commercial sources and used without purification. All of them were analytical grade. The commercially swim bladders, isinglass, were purchased from grocery store. All methods were carried out in accordance with relevant guidelines and regulations. The known products were identified by comparison of their melting points. Melting points were determined in open capillaries using an Electrothermal 9100 instrument. Infrared (IR) spectra were acquired on a Shimadzu FT-IR-8400S spectrometer with spectroscopic grade $\mathrm{KBr}$. The ${ }^{1} \mathrm{HNMR}(500 \mathrm{MHz})$ were obtained on a 
Bruker Avance DPX-300 instrument. The spectra were obtained in DMSO-d6 relative to TMS as internal standard. Scanning electron microscopy (SEM) was recorded on a VEG2/TESCAN 30kv with gold coating, and energy dispersive X-ray spectroscopy (EDX) was recorded on a VEG//TESCAN-XMU.

\section{General procedure for the preparation of the $\mathrm{Fe}_{3} \mathrm{O}_{4} \mathrm{NPs}$}

The superparamagnetic iron oxide nanoparticles (SPIONs) were synthesized using a co-precipitation method described before ${ }^{55,56}$. In a brief, $\mathrm{FeCl}_{3} \cdot 6 \mathrm{H}_{2} \mathrm{O}(1.215 \mathrm{~g})$ and $\mathrm{FeCl}_{2} \cdot 4 \mathrm{H}_{2} \mathrm{O}(0.637 \mathrm{~g})\left(\mathrm{Fe}^{2+} / \mathrm{Fe}^{3+}=1: 2\right)$ were dissolved in deionized water $(20 \mathrm{~mL})$ under an inert atmosphere to get a homogenous solution. Chemical precipitation was carried out by the slow addition of $\mathrm{NaOH}$ solution $(25 \%)$, stirring vigorously at $80^{\circ} \mathrm{C}$ for 60 min, until the $\mathrm{pH}=10$ was attained. The obtained magnetic particles were separated by an external magnetic field, washed three times with deionized water and ethanol $(25 \mathrm{~mL})$, and dried in a 65 ${ }^{\circ} \mathrm{C}$ oven for $24 \mathrm{~h}$.

\section{General procedure for the preparation of $\mathrm{Fe}_{3} \mathrm{O}_{4} @ \mathrm{SiO}_{2}$.}

Initially, $\mathrm{Fe}_{3} \mathrm{O}_{4}(1 \mathrm{~g})$ and $\mathrm{DI}$ water $(50 \mathrm{~mL})$ were for $30 \mathrm{~min}$. Then, ammonia $(5 \mathrm{ml})$ and $50 \mathrm{ml}$ ethanol were added to the flask followed by adding $1.5 \mathrm{ml}$ TEOS. The mixture was stirred for $24 \mathrm{~h}$ in room temperature. The prepared $\mathrm{Fe}_{3} \mathrm{O}_{4} @ \mathrm{SiO}_{2}$ was magnetically separated, washed sequentially with water and ethanol and dried in a vacuum oven at $50^{\circ} \mathrm{C}$.

\section{General procedure for the preparation of $\mathrm{Fe}_{3} \mathrm{O}_{4} @ \mathrm{SiO}_{2} / \mathrm{ECH}$}

$\mathrm{Fe}_{3} \mathrm{O}_{4} @ \mathrm{SiO}_{2}(1 \mathrm{~g})$ was mixed with $1 \mathrm{ml} \mathrm{ECH}$ and $3 \mathrm{ml}$ of ethanol and stirred for $5 \mathrm{~h}$ at $60^{\circ} \mathrm{C}$. The resulted precipitate was then washed and dried in a vacuum oven at $50^{\circ} \mathrm{C}$.

\section{General procedure for the preparation of $\mathrm{Fe}_{3} \mathrm{O}_{4} @ \mathrm{SiO}_{2} / \mathrm{ECH} / \mathrm{IG}$}

$0.1 \mathrm{~g}$ of the dried precipitate was dissolved in $20 \mathrm{ml}$ ethanol and mixed with $0.2 \mathrm{~g}$ isinglass. The mixture was sonicated for $30 \mathrm{~min}$ and then stirred for $1 \mathrm{~h}$. As before the obtained precipitate was washed and dried.

\section{General experimental procedure for the synthesis of benzimidazoles derivatives catalysed by $\mathrm{Fe}_{3} \mathrm{O}_{4} @ \mathrm{SiO}_{2} / \mathrm{ECH} / \mathrm{IG}$}

A mixture of isatin $(1 \mathrm{mmol})$, malononitrile $(1 \mathrm{mmol})$, various 1,3 dicarbonyls $(1 \mathrm{mmol})$, and $\mathrm{Fe}_{3} \mathrm{O}_{4} @ \mathrm{SiO}_{2} / \mathrm{ECH} / \mathrm{IG}(0.02 \mathrm{~g})$ in EtOH/water (1:1) had been stirred for an appropriate period of time. After completion of the reaction as indicated by TLC, the reaction mixture had been dissolved in hot ethanol and the catalyst was recovered by external magnet, washed, dried and then reused in successive reaction. The reaction mixture had been recrystallized with ethanol to afford pure desired substituted benzimidazoles. 


\section{Conclusions}

In summary, we devised a novel collagen-coated superparamagnetic organic-inorganic hybrid catalyst, $\mathrm{Fe}_{3} \mathrm{O}_{4} @ \mathrm{SiO}_{2} / \mathrm{ECH} / \mathrm{IG}$, which exhibited radically enhanced catalytic activity in the synthesis of a wide range of substituted spirooxindole derivatives through a one pot atom economical process. This bifunctional heterogeneous catalyst efficiency is achieved in several aspects, such as high product yields under mild conditions, stability, recyclability, and high reaction rate.

\section{References}

1 Zhao, Z.-S., Zhang, Y., Fang, T., Han, Z.-B. \& Liang, F.-S. Chitosan-Coated Metal-OrganicFramework Nanoparticles as Catalysts for Tandem Deacetalization-Knoevenagel Condensation Reactions. ACS Applied Nano Materials 3, 6316-6320 (2020).

2 Veisi, H., Ozturk, T., Karmakar, B., Tamoradi, T. \& Hemmati, S. In situ decorated Pd NPs on chitosan-encapsulated Fe304/SiO2-NH2 as magnetic catalyst in Suzuki-Miyaura coupling and 4nitrophenol reduction. Carbohydrate polymers 235, 115966 (2020).

3 Amirnejat, S., Nosrati, A., Javanshir, S. \& Naimi-Jamal, M. R. Superparamagnetic alginate-based nanocomposite modified by L-arginine: An eco-friendly bifunctional catalysts and an efficient antibacterial agent. International journal of biological macromolecules 152, 834-845 (2020).

$4 \quad$ Ali, F., Khan, S. B., Shaheen, N. \& Zhu, Y. Z. Eggshell membranes coated chitosan decorated with metal nanoparticles for the catalytic reduction of organic contaminates. Carbohydrate Polymers, 117681 (2021).

5 Zhou, Y., Shen, J., Bai, Y., Li, T. \& Xue, G. Enhanced degradation of Acid Red 73 by using cellulose-based hydrogel coated Fe304 nanocomposite as a Fenton-like catalyst. International journal of biological macromolecules 152, 242-249 (2020).

6 Ohata, J., Martin, S. C. \& Ball, Z. T. Metal-Mediated Functionalization of Natural Peptides and Proteins: Panning for Bioconjugation Gold. Angewandte Chemie International Edition 58, 6176-6199 (2019).

$7 \quad \mathrm{Li}, \mathrm{X}$. et al. Highly active enzyme-metal nanohybrids synthesized in protein-polymer conjugates. Nature Catalysis 2, 718-725 (2019).

$8 \quad$ Patel, S. K. et al. Synthesis of cross-linked protein-metal hybrid nanoflowers and its application in repeated batch decolorization of synthetic dyes. Journal of hazardous materials 347, 442-450 (2018).

9 Patel, S. K., Otari, S. V., Kang, Y. C. \& Lee, J.-K. Protein-inorganic hybrid system for efficient histagged enzymes immobilization and its application in L-xylulose production. RSC advances 7, 3488-3494 (2017). 
by metal-nucleotide hydrogelnanofibers for improving stability and recycling. Molecules 22, 179 (2017).

11 Mylkie, K., Nowak, P., Rybczynski, P. \& Ziegler-Borowska, M. Polymer-Coated Magnetite Nanoparticles for Protein Immobilization. Materials 14, 248 (2021).

12 Saneinezhad, S., Mohammadi, L., Zadsirjan, V., Bamoharram, F. F. \& Heravi, M. M. Silver nanoparticles-decorated Preyssler functionalized cellulose biocomposite as a novel and efficient catalyst for the synthesis of 2-amino-4 H-pyrans and spirochromenes. Scientific reports 10, 1-26 (2020).

13 Dolatkhah, Z., Javanshir, S., Bazgir, A. \& Hemmati, B. Palladium on magnetic Irish moss: A new nano-biocatalyst for suzuki type cross-coupling reactions. Applied Organometallic Chemistry 33, e4859 (2019).

14 Liu, Y., Xu, H., Yu, H., Yang, H. \& Chen, T. Synthesis of lignin-derived nitrogen-doped carbon as a novel catalyst for 4-NP reduction evaluation. Scientific reports 10, 1-14 (2020).

15 Tan, J. M., Bullo, S., Fakurazi, S. \& Hussein, M. Z. Preparation, characterisation and biological evaluation of biopolymer-coated multi-walled carbon nanotubes for sustained-delivery of silibinin. Scientific Reports 10, 1-15 (2020).

16 Çalışkan, M. \& Baran, T. Decorated palladium nanoparticles on chitosan/ $\delta$-FeOOH microspheres: A highly active and recyclable catalyst for Suzuki coupling reaction and cyanation of aryl halides. International Journal of Biological Macromolecules (2021).

17 Nasrollahzadeh, M., Shafiei, N., Nezafat, Z., Bidgoli, N. S. S. \& Soleimani, F. Recent progresses in the application of cellulose, starch, alginate, gum, pectin, chitin and chitosan based (nano) catalysts in sustainable and selective oxidation reactions: A review. Carbohydrate Polymers, 116353 (2020).

18 Banazadeh, M., Amirnejat, S. \& Javanshir, S. Synthesis, Characterization, and Catalytic Properties of Magnetic Fe304@ FU: A Heterogeneous Nanostructured Mesoporous Bio-Based Catalyst for the Synthesis of Imidazole Derivatives. Frontiers in chemistry 8 (2020).

19 Veisi, H., Mohammadi, L., Hemmati, S., Tamoradi, T. \& Mohammadi, P. In situ immobilized silver nanoparticles on rubia tinctorum extract-coated ultrasmall iron oxide nanoparticles: an efficient nanocatalyst with magnetic recyclability for synthesis of propargylamines by A3 coupling reaction. ACS omega 4, 13991-14003 (2019).

20 Rajabi-Moghaddam, H., Naimi-Jamal, M. \& Tajbakhsh, M. Fabrication of copper (II)-coated magnetic core-shell nanoparticles Fe 30 4@SiO 2-2-aminobenzohydrazide and investigation of its catalytic application in the synthesis of 1, 2, 3-triazole compounds. Scientific Reports 11, 1-14 (2021).

21 Javanshir, S., Pourshiri, N. S., Dolatkhah, Z. \& Farhadnia, M. Caspian Isinglass, a versatile and sustainable biocatalyst for domino synthesis of spirooxindoles and spiroacenaphthylenes in water. 
Monatshefte für Chemie-Chemical Monthly 148, 703-710 (2017).

22 Dekamin, M. G. et al. Sodium alginate: An efficient biopolymeric catalyst for green synthesis of 2-amino-4H-pyran derivatives. International journal of biological macromolecules 87, 172-179 (2016).

23 Hemmati, B., Javanshir, S. \& Dolatkhah, Z. Hybrid magnetic Irish moss/Fe 304 as a nanobiocatalyst for synthesis of imidazopyrimidine derivatives. RSC advances 6, 50431-50436 (2016).

24 Dolatkhah, Z., Javanshir, S., Bazgir, A. \& Mohammadkhani, A. Magnetic Isinglass a Nano-Bio Support for Copper Immobilization: Cu-IG@ Fe304 a Heterogeneous Catalyst for Triazoles Synthesis. ChemistrySelect 3, 5486-5493 (2018).

25 Pourian, E., Javanshir, S., Dolatkhah, Z., Molaei, S. \& Maleki, A. Ultrasonic-assisted preparation, characterization, and use of novel biocompatible core/shell Fe304@GA@ isinglass in the synthesis of 1, 4-dihydropyridine and $4 \mathrm{H}$-pyran derivatives. ACS omega 3, 5012-5020 (2018).

26 Dolatkhah, Z., Javanshir, S. \& Bazgir, A. Isinglass-palladium as collagen peptide-metal complex: a highly efficient heterogeneous biocatalyst for Suzuki cross-coupling reaction in water. Journal of the Iranian Chemical Society 16, 1473-1481 (2019).

27 Burate, P. A., Javle, B. R., Desale, P. H. \& Kinage, A. K. Amino acid amide based ionic liquid as an efficient organo-catalyst for solvent-free Knoevenagel condensation at room temperature. Catalysis Letters 149, 2368-2375 (2019).

28 Wang, J. et al. Efficient conversion of N-acetyl-d-glucosamine into nitrogen-containing compound 3-acetamido-5-acetylfuran using amino acid ionic liquid as the recyclable catalyst. Science of The Total Environment 710, 136293 (2020).

29 Demurtas, M. et al. Indole derivatives as multifunctional drugs: Synthesis and evaluation of antioxidant, photoprotective and antiproliferative activity of indole hydrazones. Bioorganic chemistry $\mathbf{8 5}$, 568-576 (2019).

30 Nájera, C. \& Sansano, J. M. Synthesis of pyrrolizidines and indolizidines by multicomponent 1, 3dipolar cycloaddition of azomethine ylides. Pure and Applied Chemistry 91, 575-596 (2019).

31 Karimi, A. R. \& Sedaghatpour, F. Novel mono-and bis (spiro-2-amino-4H-pyrans): alum-catalyzed reaction of 4-hydroxycoumarin and malononitrile with isatins, quinones, or ninhydrin. Synthesis 2010, $1731-1735$ (2010).

32 He, T., Zeng, Q.-Q., Yang, D.-C., He, Y.-H. \& Guan, Z. Biocatalytic one-pot three-component synthesis of 3, 3'-disubstituted oxindoles and spirooxindole pyrans using a-amylase from hog pancreas. RSC Advances 5, 37843-37852 (2015). 

immobilized sulfonic acid on the cobalt ferrite magnetic nanocatalyst (CoFe 204 4iO 2@ SO $3 \mathrm{H}$ ) in the synthesis of spirooxindoles. Research on Chemical Intermediates 45, 5665-5680 (2019).

34 Baharfar, R., Zareyee, D. \& Allahgholipour, S. L. Synthesis and characterization of MgO nanoparticles supported on ionic liquid-based periodic mesoporous organosilica (MgO@ PMO-IL) as a highly efficient and reusable nanocatalyst for the synthesis of novel spirooxindole-furan derivatives. Applied Organometallic Chemistry 33, e4805 (2019).

35 Naeimi, H. \& Lahouti, S. Sulfonated chitosan encapsulated magnetically Fe 304 nanoparticles as effective and reusable catalyst for ultrasound-promoted rapid, three-component synthesis of spiro-4Hpyrans. Journal of the Iranian Chemical Society 15, 2017-2031 (2018).

36 Khoobi, M. et al. Polyethyleneimine-modified superparamagnetic Fe304 nanoparticles: An efficient, reusable and water tolerance nanocatalyst. Journal of Magnetism and Magnetic Materials $\mathbf{3 7 5}$, 217-226 (2015).

37 Jamatia, R., Gupta, A. \& Pal, A. K. Nano-FGT: a green and sustainable catalyst for the synthesis of spirooxindoles in aqueous medium. RSC advances 6, 20994-21000 (2016).

38 Elinson, M. N., Ryzhkov, F. V., Zaimovskaya, T. A. \& Egorov, M. P. Solvent-free multicomponent assembling of isatins, malononitrile, and dimedone: fast and efficient way to functionalized spirooxindole system. Monatshefte für Chemie-Chemical Monthly 147, 755-760 (2016).

39 Mamaghani, M., Tabatabaeian, K., Pourshiva, M. \& Nia, R. H. Rapid and efficient synthesis of spiro-oxindoles using Fe3+-montmorillonite under ultrasonic irradiation. Journal of Chemical Research 39, 314-317 (2015).

40 Keshavarz, M. Ion-pair immobilization of I-prolinate anion onto cationic polymer support and a study of its catalytic activity for one-pot synthesis of spiroindolones. Journal of the Iranian Chemical Society 13, 553-561 (2016).

41 Baharfar, R. \& Azimi, R. Immobilization of 1, 4-diazabicyclo [2.2. 2] Octane (DABCO) over mesoporous silica SBA-15: an efficient approach for the synthesis of functionalized spirochromenes. Synthetic Communications 44, 89-100 (2014).

42 Goli-Jolodar, O., Shirini, F. \& Seddighi, M. Introduction of a novel basic ionic liquid containing dual basic functional groups for the efficient synthesis of spiro-4H-pyrans. Journal of Molecular Liquids 224, 1092-1101 (2016).

43 Mohamadpour, F., Maghsoodlou, M. T., Lashkari, M., Heydari, R. \& Hazeri, N. Synthesis of Quinolines, Spiro [4 H-pyran-oxindoles] and Xanthenes Under Solvent-Free Conditions. Organic Preparations and Procedures International 51, 456-476 (2019). 
44 Nagaraju, S., Paplal, B., Sathish, K., Giri, S. \& Kashinath, D. Synthesis of functionalized chromene and spirochromenes using I-proline-melamine as highly efficient and recyclable homogeneous catalyst at room temperature. Tetrahedron letters 58, 4200-4204 (2017).

45 Moradi, L., Ataei, Z. \& Zahraei, Z. Convenient synthesis of spirooxindoles using SnO 2 nanoparticles as effective reusable catalyst at room temperature and study of their in vitro antimicrobial activity. Journal of the Iranian Chemical Society 16, 1273-1281 (2019).

46 Wagh, Y. B., Padvi, S. A., Mahulikar, P. P. \& Dalal, D. S. CsF promoted rapid synthesis of spirooxindole-pyran annulated heterocycles at room temperature in ethanol. Journal of Heterocyclic Chemistry 57, 1101-1110 (2020).

47 Chandam, D. R., Mulik, A. G., Patil, D. R. \& Deshmukh, M. B. Oxalic acid dihydrate: proline as a new recyclable designer solvent: a sustainable, green avenue for the synthesis of spirooxindole. Research on Chemical Intermediates 42, 1411-1423 (2016).

48 Wang, G. D., Zhang, X. N. \& Zhang, Z. H. One-Pot Three-Component Synthesis of Spirooxindoles Catalyzed by Hexamethylenetetramine in Water. Journal of Heterocyclic Chemistry 50, 61-65 (2013).

49 Meshram, H. M., Kumar, D. A., Prasad, B. R. V. \& Goud, P. R. Efficient and convenient polyethylene glycol (PEG)-mediated synthesis of spiro-oxindoles. Helvetica Chimica Acta 93, 648 (2010).

50 Baghernejad, M., Khodabakhshi, S. \& Tajik, S. Isatin-based three-component synthesis of new spirooxindoles using magnetic nano-sized copper ferrite. New Journal of Chemistry 40, 2704-2709 (2016).

51 Kidwai, M., Jahan, A. \& Mishra, N. K. Gold (III) chloride (HAuCl4· 3H2O) in PEG: A new and efficient catalytic system for the synthesis of functionalized spirochromenes. Applied Catalysis A: General 425, 35-43 (2012).

52 Padvi, S. A., Tayade, Y. A., Wagh, Y. B. \& Dalal, D. S. [bmim] OH: An efficient catalyst for the synthesis of mono and bis spirooxindole derivatives in ethanol at room temperature. Chinese Chemical Letters 27, 714-720 (2016).

53 Khot, S. S., Anbhule, P. V., Desai, U. V. \& Wadgaonkar, P. P. Tris-hydroxymethylaminomethane (THAM): an efficient organocatalyst in diversity-oriented and environmentally benign synthesis of spirochromenes. Comptes Rendus Chimie 21, 814-821 (2018).

54 Brahmachari, G. \& Banerjee, B. Facile and Chemically Sustainable One-Pot Synthesis of a Wide Array of Fused O-and N-Heterocycles Catalyzed by Trisodium Citrate Dihydrate under Ambient Conditions. Asian Journal of Organic Chemistry 5, 271-286 (2016).

55 Dangolani, S. K., Panahi, F., Nourisefat, M. \& Khalafi-Nezhad, A. 4-Dialkylaminopyridine modified magnetic nanoparticles: as an efficient nano-organocatalyst for one-pot synthesis of 2-amino-4 H- 
chromene-3-carbonitrile derivatives in water. RSC advances 6, 92316-92324 (2016).

56 Mohammadfam, Y., Heris, S. Z. \& Khazini, L. Experimental Investigation of Fe304/hydraulic oil magnetic nanofluids rheological properties and performance in the presence of magnetic field. Tribology International 142, 105995 (2020).

\section{Figures}

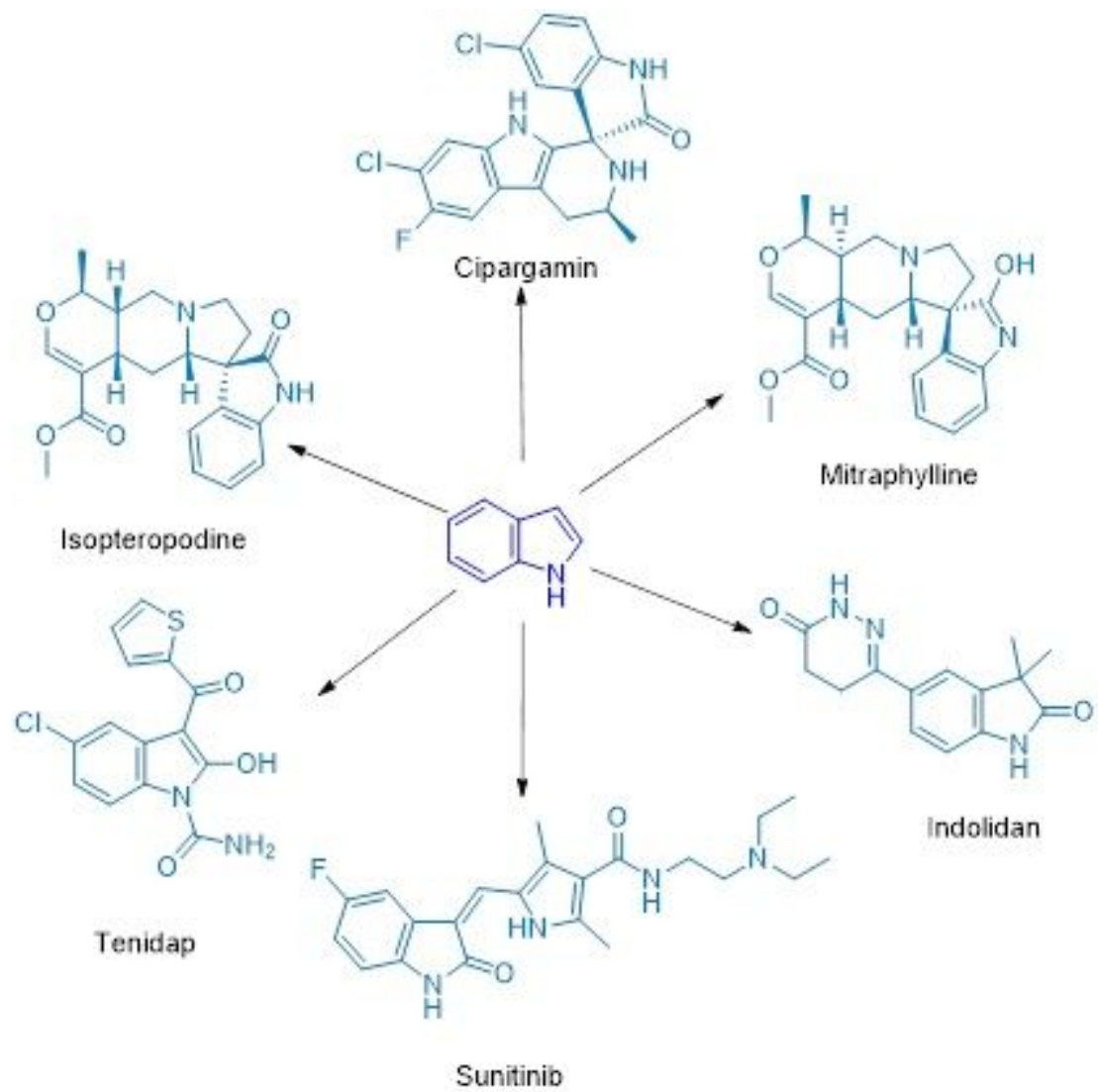

\section{Figure 1}

Some biologically active oxindoles and spirooxindoles

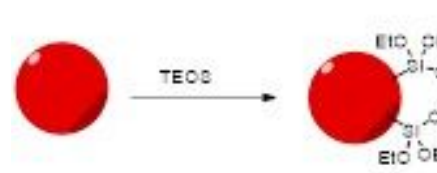

$\mathrm{FeP}_{3}$
Eokfilerehyathe

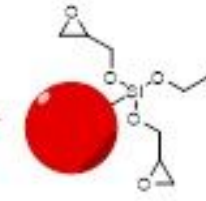

$\mathrm{Fe}, \mathrm{O}_{4} \mathrm{O}, \mathrm{OlO}, \mathrm{ECH}$

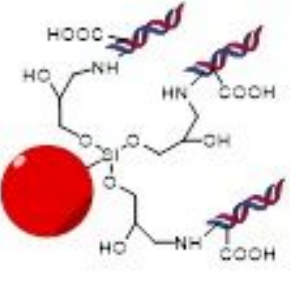

Fe. $0.0010-\mathrm{EOH}+19$

Figure 2 
Schematic representation of the catalyst synthesis procedures.
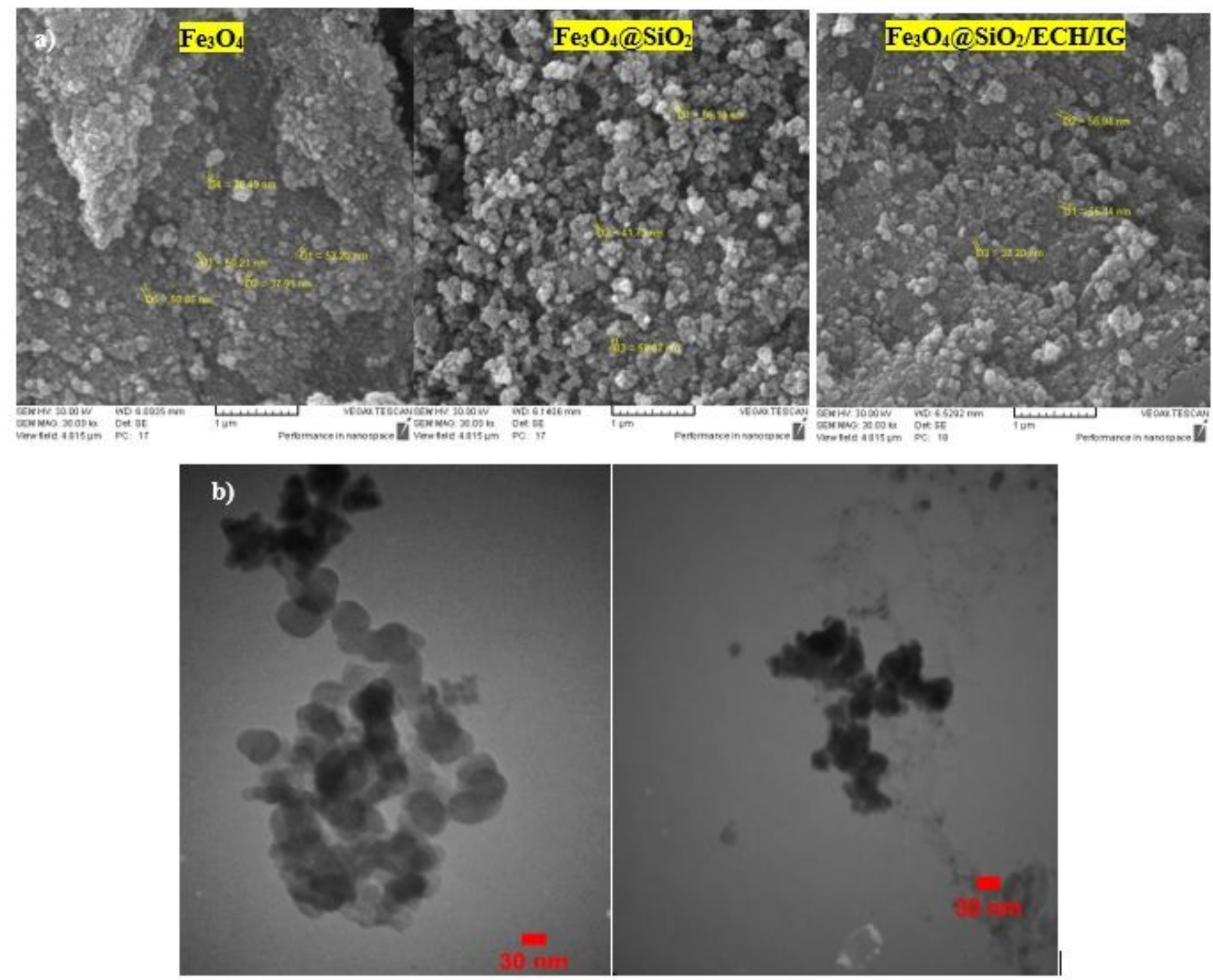

\section{Figure 3}

a) SEM images of Fe304, Fe3O4@SiO2 and Fe3O4@SiO2/ECH/IG and b) TEM images of Fe304@SiO2/ECH/IG 

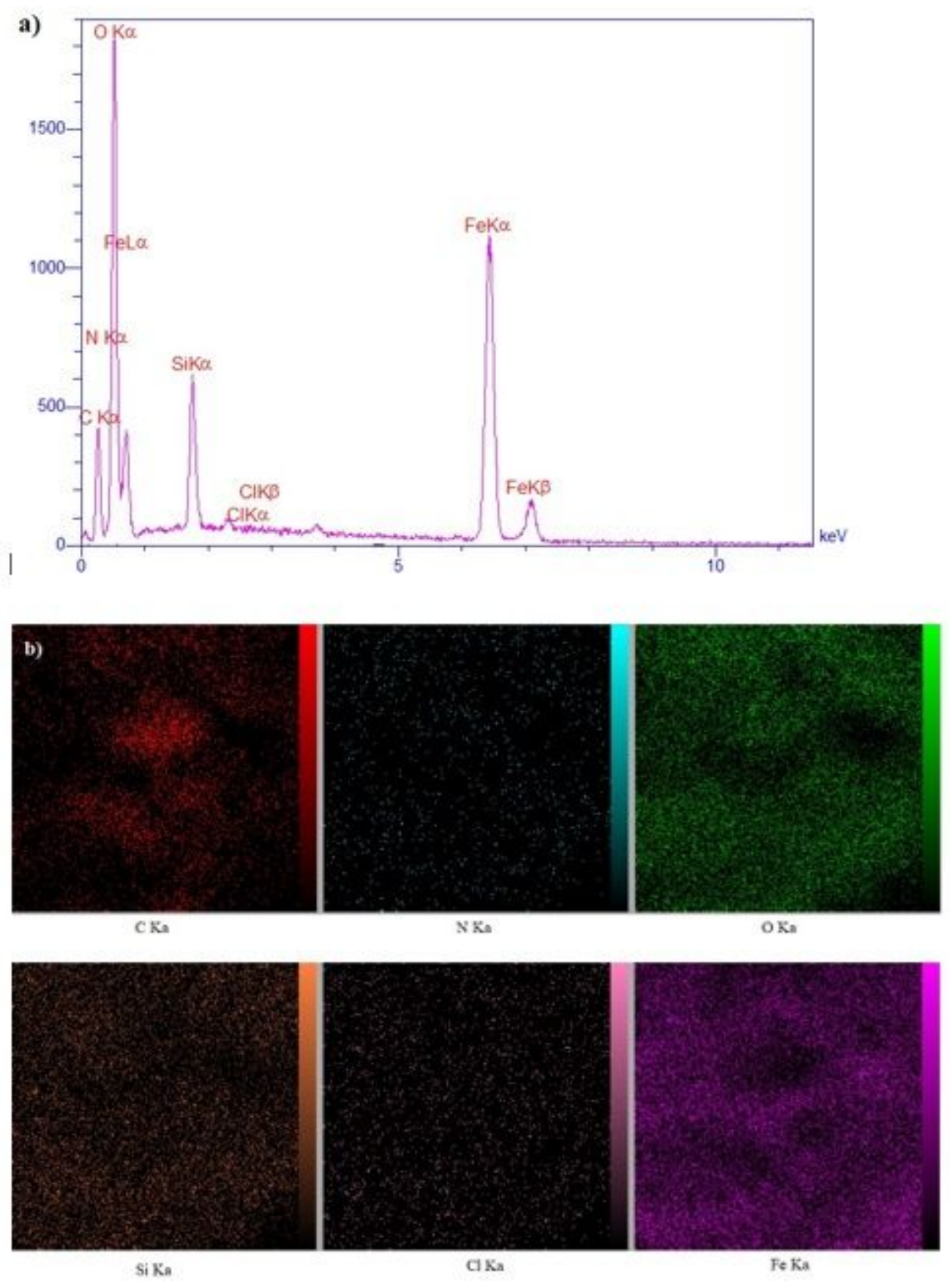

Figure 4

Energy dispersive X-ray analysis (EDX) of Fe304@SiO2/ECH/IG and b) elemental mapping of C (red); N (blue), $\mathrm{O}$ (green), Fe (violet), Si (orange) and Cl (pink) atoms for Fe304@SiO2/ECH/IG. 


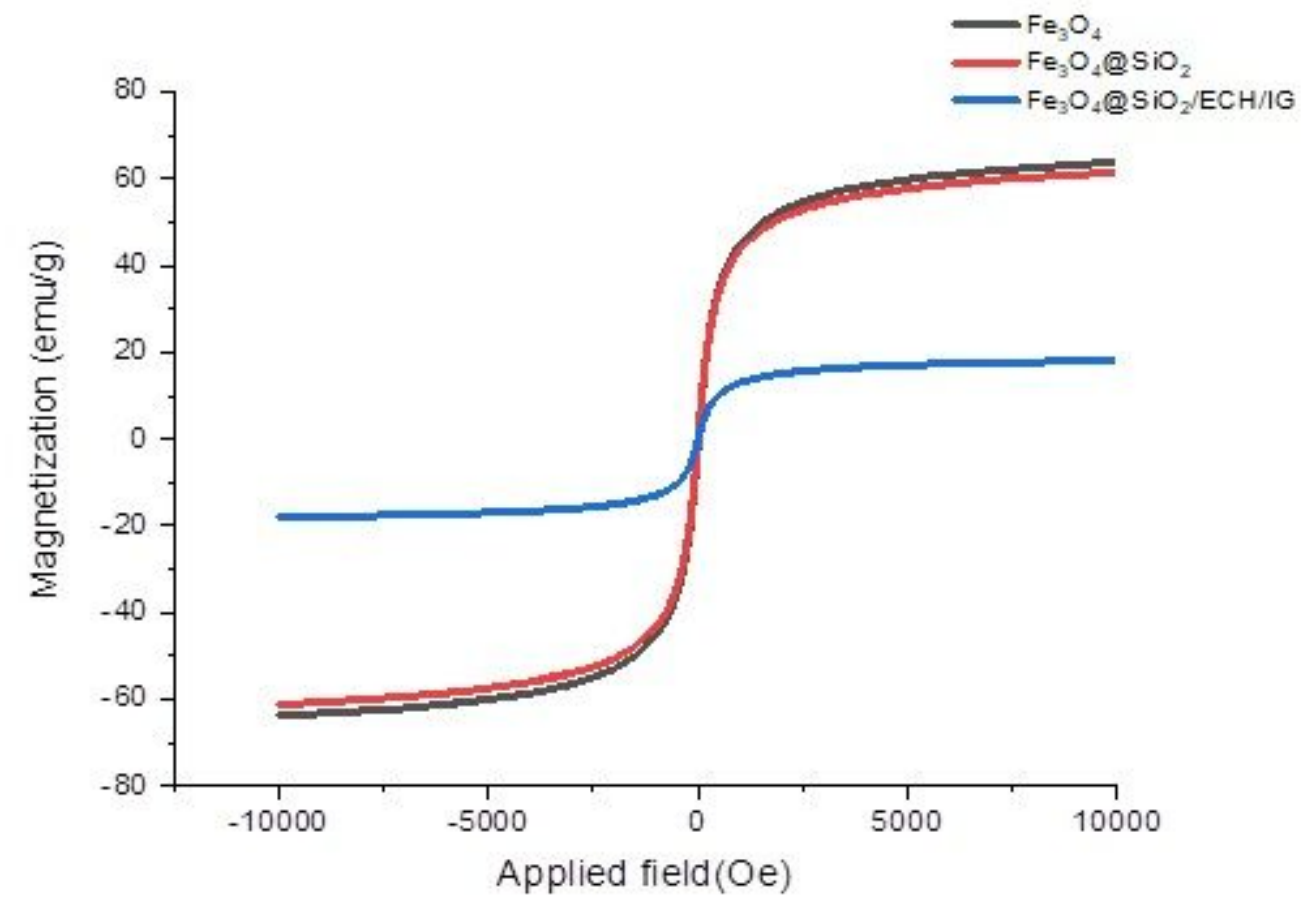

Figure 5

VSM analysis of the prepared Fe304@SiO2/ECH/IG.

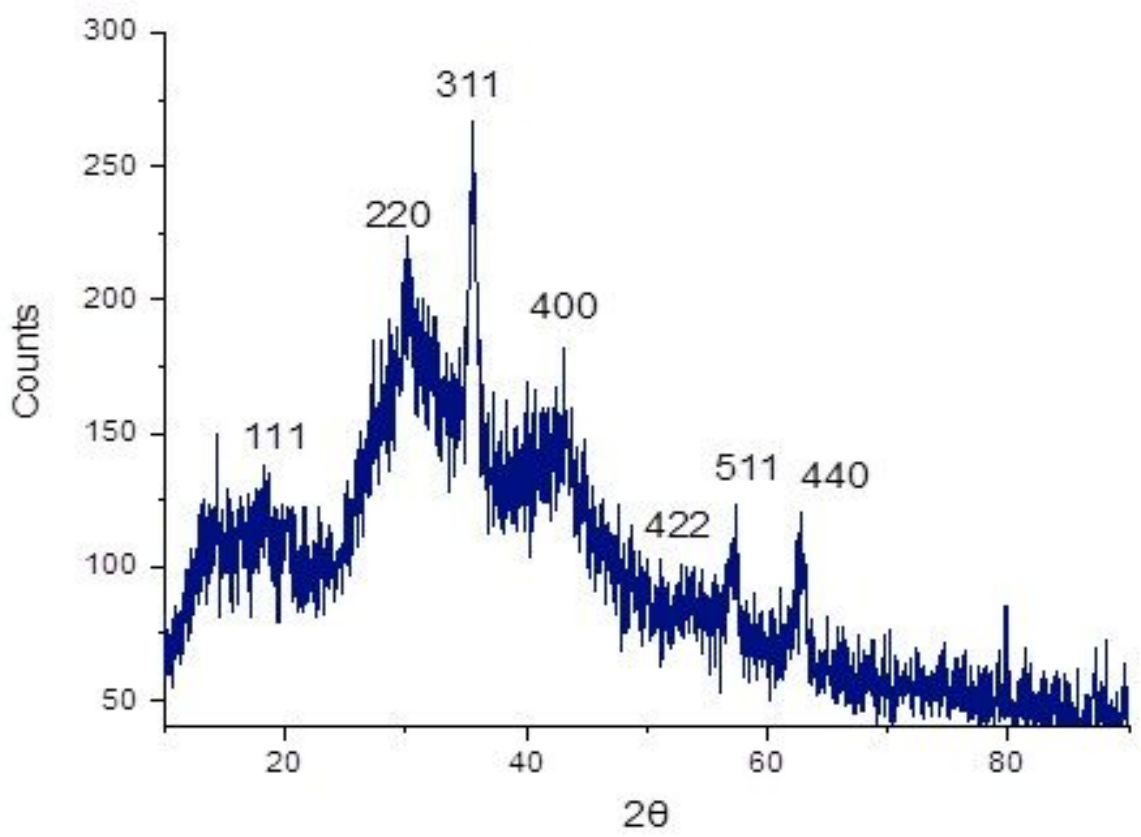

Figure 6

XRD pattern of Fe304@SiO2/ECH/IG. 


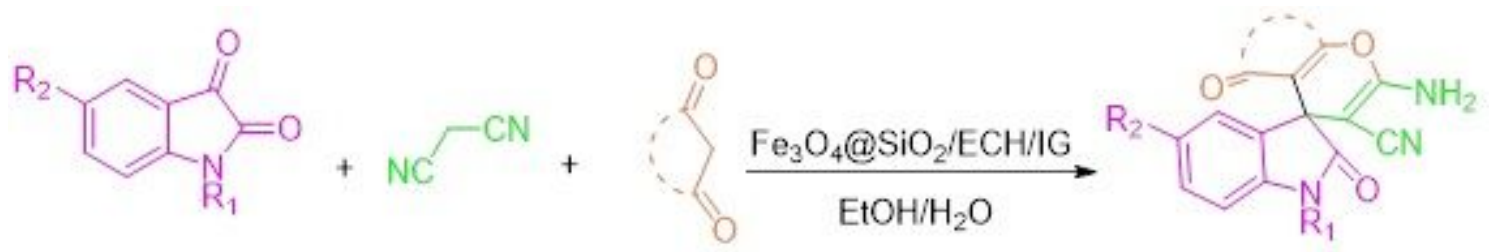

1

2

3a-e

4a-t

\begin{abstract}
$\mathrm{R} 1=\mathrm{H}, \mathrm{Bn}, \mathrm{Me}$
\end{abstract}
$\mathrm{R} 2=\mathrm{NO} 2, \mathrm{Cl}$<smiles>CC1(C)CC(=O)CC(=O)C1</smiles>

$3 a$<smiles>O=C1CCCC(=O)C1</smiles>

$3 b$

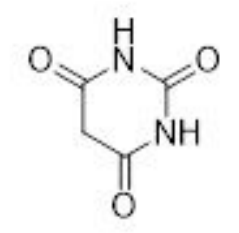

3c<smiles>O=C1CC(=O)NC(=S)N1</smiles>

3d<smiles>O=c1cc(O)c2ccccc2o1</smiles>

$3 e$

\title{
Figure 7
}

Schematic representation of the Fe304@SiO2/ECH/IG and its catalytic activity in the one-pot synthesis of spirooxindole derivatives (4a-t) through multicomponent reaction (MCR) strategy. 


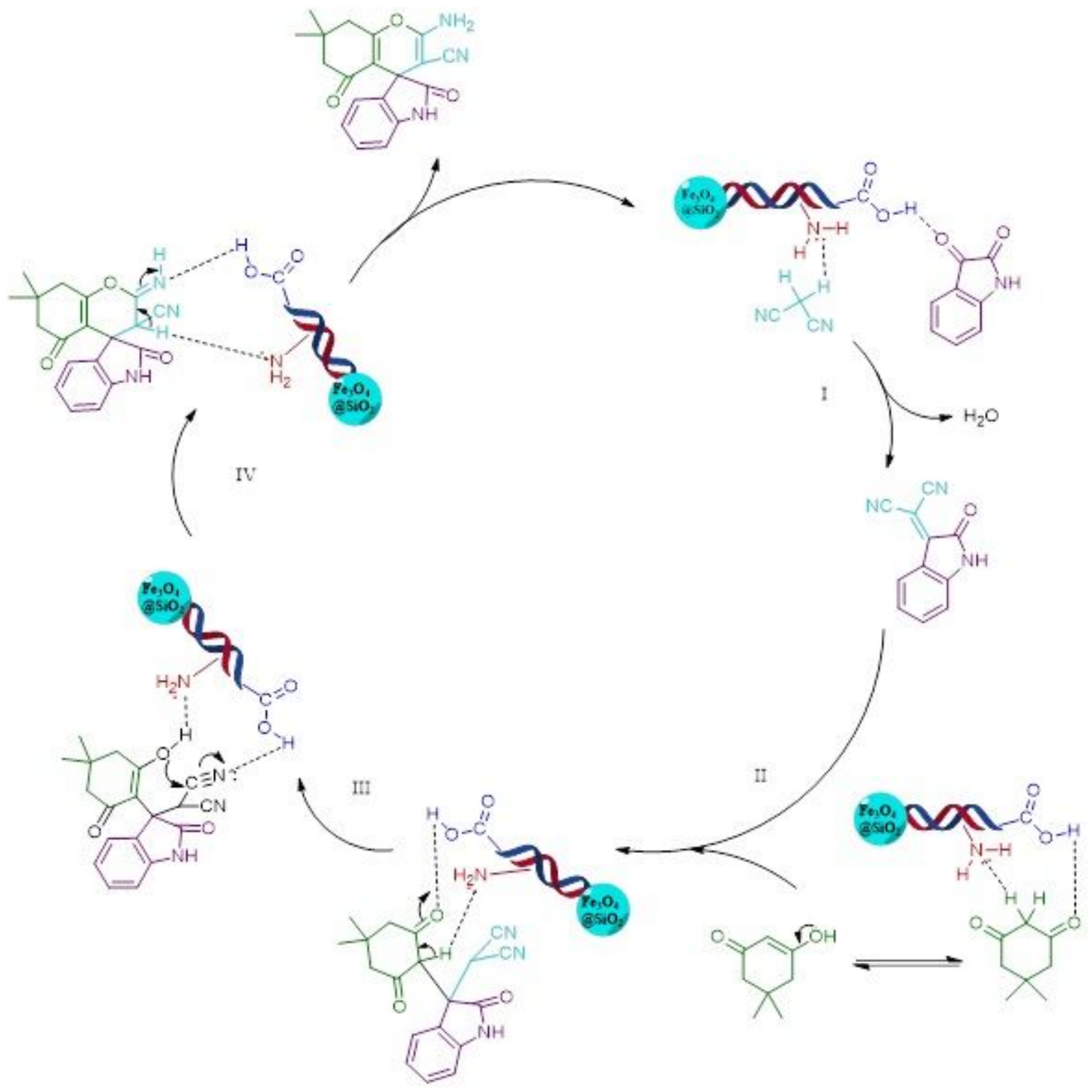

Figure 8

Proposed catalytic mechanism of Fe304@SiO2/ECH/IG.

\section{Supplementary Files}

This is a list of supplementary files associated with this preprint. Click to download.

- Supplementarymaterial.docx 